\section{6 Geoglossum Fungi of Japan}

A VERY detajled account of "Geoglossaceæ Japoniæ" is gipen by Sanshi Imai in the Journal of the Factlty efiAgriculture, Hokkaido Imperial Univer$\operatorname{sic}(45$, Pt 4, 155, 10 plates; October 1941). Thirty. serd spec of with three varieties and thirteen forms are fescribed. About 24 per cent are endemic, 76 Ner dent are common with North America (among which 24 per cent are confined to the two regions) and 51 per cent are common with Europe. The author proposes three sub-families for the Japanese Geoglossace -Geoglossoideæ, Cudonioideæ and Hemiglossoider-and all the species and forms are criticadly described.

भi)

Scientific Papers of the Middle East

A THIRD "List of Scientific Papers published in the Middle East", cov fol those received during August 1, 1948-March 15,349 , by the Science Co-operation Office, Mipd l Eadt, of the United Nations Educational, Scientific and Cultural Organisation, has recenty been published (No. 3 ; pp. 58; Cairo, 1949). The list is classified by subjects according to the Ehiversal Decimal Classification and is provided with an alphabetical list of periodicals and serials indexed, arranged by countries. Some brief notes on the activities of the Office are included. In style and production the present List is a great improvement on earlier lists and is well designed to further its purpose of facilitating the exchange of literature and of increasing the opportunities for scientific workers to benefit from the contributions of the Middle East to science. \section{South American Congress of Research Workers
in Agronomy}

A PPROXIMATELy three hundred research workers are expected to paticipate in the first South American Congress of Research Workers in Agronomy, of whom some 220 vill represent the Argentine, Brazil and Uruguay and the remainder will come from the other Soxplatmerican countries and the United States. Thp Congress will be held during November 13-19, and the meeting place will be the Experiment Station of La Estanzuela in Uruguay, suitable alike for its relatively central position and for the signal services it has rendered to South American agricultural research. Five sections will discuss (1) climate and soil, or general ecological questions; (2) crops and herbage husbandry; (3) animal husbandry ; (4) the industrialization of agricultural products; and (5) agriculture and the man, or rural sociology and economics, including marketing problems. Organ. isation is in the hands of a Uruguayan committee representing government and university authorities under the presidency of Dr. A. Boerger, director of La Estanzuela. The problems to be attacked are such as have no national frontiers but are confined solely by ecological limits.

\section{University of Sheffield}

THE fllowing appointments have been recently made h the University of Sheffield: Dr. M. Holt and pr. D. R. Davies to be lecturers in applied mathematics; J. Webster to be lecturer in botany; J. K. A. Beverley to be lecturer in bacteriology; J. W. Roe to be lecturer in industrial hygiene; Dr. J. C. Appleby to be bacteriologist in the Department of Medicine.
October 29, 1949

Vol. 164

The Night Sky in November

FULL moon occurston Nov. 5d. 21h. 09m., U.T. and new mogrowov. 20d. 07h. $29 \mathrm{~m}$. The following conjunctions wh the moon take place: Nov. 15d. 01h., MrSic S.; Nov. 15d. 14h., Saturn 0.8 S.; Do $23 d$. 19h., Venus $2^{\circ}$ N. ; Nov. 24d. 13h., Jupiter $5^{\circ}$ in. In addition to these conjunctions with the mon, Mars is in conjunction with Saturn on Nov. 30d. 21h., Mars being $0 \cdot 2^{\circ} \mathrm{N}$. Mercury rises about $1 \frac{1}{4} \mathrm{hr}$. before the sun on Nov. 1 and is visible in the eastern sky, but draws closer to the sun and is in superior conjunction on Nov. 21. Venus sets about two hours after the sun and is conspicuous in the western sky, stellar magnitude -4 , the visible portion of the illuminated disk varying between 0.6 and $0 \cdot 44$. Mars rises soon after midnight throughout the month. Jupiter sets at $21 \mathrm{~h}$. $10 \mathrm{~m} ., 20 \mathrm{~h} .25 \mathrm{~m}$. and 19h. $40 \mathrm{~m}$. on Nov. 1,15 and 30 respectively, but in the latitude of Greenwich does not rise more than $18^{\circ}$ above the horizon. Saturn, in the constellation of Leo, rises at $2 \mathrm{~h}$., $1 \mathrm{~h}$. $10 \mathrm{~m}$. and $0 \mathrm{~h}$. $15 \mathrm{~m}$. at the beginning, middle and end of the month respectively. Occultations of stars brighter than magnitude 6 are as follows: Nov. 3 d. $20 \mathrm{~h} .30 \cdot 4 \mathrm{~m}$., $\zeta$ Pisc. $(D)$; Nov. lod. 2lh. $32 \cdot 1 \mathrm{~m} ., 47$ Gemi. $(R)$. $D$ and $R$ refer to disappearance and reappearance respectively, and the latitude of Greenwich is assumed. The Leonid meteors are due during Nov, 14-19 and the Andromedids during Nov. 18-23, but these showers are now feeble and supply comparatively few meteors.

\section{Announcements}

Mr. C. P. MEREDITH, lecturer in educational psychology in the University of Leeds, has been appointed professor of psychology.

DR. R. A. V. RAFF, a specialist in high-polymer research, haspoen appointed to a new fellowship on plastics established in the Mellon Institute by Koppers Company, Inc. Dr. Rafi was previously for eight years employed by Howard Smith Paper Mills, Ltd., Cornwall, Ontario.

THE one hundred and twentieth course of Christmas Lectures at the Royal Institution "adapted to a Juvenje Auditory" will be delivered by Dr. P. Dunshlath on December 29, 31, January 3, 5, 7 and 10 at 3 p.m. He will speak on "The Electric Current".

UNDER the auspices of a group of ten organisations interested in the teaching of biology in schools, a joint conference on "The Living Body" will be held at Univergity College, London, during December 2-3. The opghing address will be given by Prof. F. R. Wintgh, who will speak on "Experimental Mam. malian Physiology". Further information can be obtained from the Secretary, British Social Hygiene Council, Tavistock House North, Tavistock Square, London, W, C.1.

ERraty. Communication on "Enzyme Activity and Niprogen Content of $E$. coli" in Nature of October 8, p. 618: (a) The last sentence in the legend to the graph should read: $Z^{2}(\mathrm{~N})$ : acid formation in atmosphere of nitrogen from glucose expressed as ml. $N / 10$ sodium hydroxide/hour/ mgm. nitrogen. (b) p. 619, col. 2, line 11 from bottom, for "daughter bacterial cell on a . . ." read "daughter bacterial cell to a...". (c) p. 619 , col. 2, line 10 from bottom, for "growth" read "formation or growth". (d) p. 619, col. 2, line 6 from bottom, for "Just after . . ." read "Just before or after . . .". (e) p. 620, line 5, omit word 'growing'. 